\title{
new community
}

Quarterly Journal of the Community Reiations Commission

Editor: Sheila PatTerson

\section{BACK ISSUES}

Vol. I No. 1

Britain, Europe and Migration

Vol. I No. 2

Community Relations and Community Work and Northern Ireland

\section{Vol. I No. 3}

Migration and Minorities

\section{Vol. I No. 4}

Community and Pluralism

Vol. I No. 5 \& Vol. II No. 1 Ethnic Minorities

Vol. II No. 1

Ethnic Minorities (continued)

Vol. II No. 2

Religious and Other Minorities and Immigration (Numbers and Policies)
Vol. 11 No. 3

Education for a Non-racial Society

Vol. II No. 4

Ethnic Minorities in Britain

Vol. III Nos. $1 \& 2$

Europe, Race and Racial Thought

Vol. III No. 3

Police and Community Relations

AND The Younger Generation

Vol. III No. 4

Exiles and Homelands, Law and

Society and the 1971 Census

Vol. IV No. 1

Migrants, Work and the Law

Vol. IV No. 2

Immigration: Characteristics, Reactions, Policies AND Children and Schooling

Forthcoming issues will include contributions on anti-discrimination law and race and community relations; race and the media; linguistics; education.

Annual subscription: Institution $£ 4.00$ (US $\$ 10.00$ ); Individual $£ 3.00$ (US $\$ 8.00$ ) per single subscription. Single copy $£ 1.00$ (US $\$ 2.50$ ).

All sales and subscriptions to: Marie Boon, Research Publications Services Ltd., Victoria Hall, East Greenwich, London SE1O ORF.

All other inquiries to: Publications Promotions Consultant, Community Relations Commission, 15/16 Bedford Street, London WC2E 9HX. 


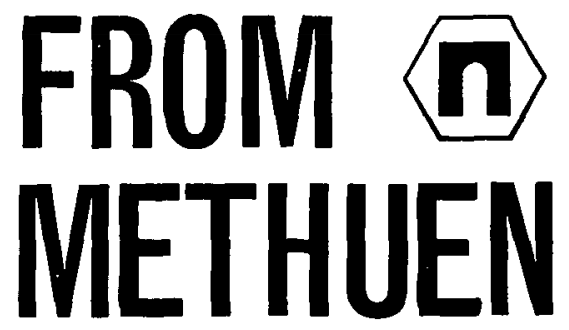

Documents on Health and Social Services: 1834 to the present day BRIAN WATKIN

This book surveys the whole range of modern social legislation, key reports and enactments from the 1834 Report of the Royal Commission on the Poor Laws up to such documents as the 1973 National Health Service Reorganization Act and the Lane Report on the Working of the Abortion Act. It will prove invaluable to students and practising administrators in the health and social services.

$£ 10.00$

University, Paperback £5.50 


\section{SOCIAL ADMINISTRATION ASSOCIATION}

The Association exists for those whose work consists mainly of teaching or research in the fields of Social Administration and Social Policy. It was formed some years ago to enable staff from universities, polytechnics, technical and other colleges, independent and Government research organisations to meet and discuss matters of common interest.

The Association holds an Annual Conference. The next one will be in Exeter on 6th, 7th and 8th July 1976. Themes will include Values in Social Policy and Comparative Social Policy and Administration.

The current membership subscription is $£ 8$ per calendar year, which includes the subscription to the Association's Journal, the Journal of Social Policy (four issues per year). The revised subscription will be announced in the next issue of the Journal-in January 1976.

Enquiries about membership should be addressed to

Bernard Meakins

Membership Secretary, Social

Administration Association

General enquiries should be addressed to

Ann Stanyer, Honorary Secretary, Social Administration Association both at

Department of Applied Social Studies, Lanchester Polytechnic, Priory Street, COVENTRY CV1 5FB 


\section{Journal of Social Policy}

NOTES FOR CONTRIBUTORS

1. All contributions and correspondence should be sent to: The Editor, Journal of Social Policy, The London School of Economics and Political Science, Houghton Street, Aldwych, London wc2A 2AE. All books for review should be sent to: The Review Editor, Journal of Social Policy, Department of Sociology and Psychology, Chelsea College, University of London, Manresa Road, London SW3 6LX.

2. Articles should generally contain between 5,000 and 10,000 words including footnotes, although longer or shorter articles may be accepted by arrangement with the Editor. Short articles stand a better chance of early publication.

3. Submission of an article is taken to imply that it has not previously been published, or is not being considered for publication elsewhere. If an author is publishing a related article elsewhere, this fact should be stated.

4. Contributions (articles, review articles, reviews) should be clearly typed on one side of the paper only using a conventional size of paper, preferably A4. All material should be typed double-spaced with generous margins. Contributors should send two copies and keep one copy of the typescript for correcting proofs.

5. Contributions should be accompanied by an abstract of between one and two hundred words.

6. References to books and articles should include the following details: in the case of books, the full title and author or authors, place of publication, publisher and date; in the case of articles, the title and author or authors, full name of the journal, volume, year and page reference (first and last page). References and other footnotes should be numbered consecutively throughout and typed separately at the end of the article. Good articles which contain this bibliographical information will be accepted, even if they do not follow the journal's own arrangement of the information.

7. Tables should be clearly laid out and designed to fit on to a page $9 \frac{1}{4} \times 6 \frac{1}{4}$ inches. Vertical lines between columns should be omitted, and horizontal lines limited to the top and bottom of the table, with an additional one below the column headings. Totals and percentages should be labelled, and units identified.

8. Contributors are advised to look through earlier issues of the journal for guidance on points of general style.

9. First proofs may be read and corrected by contributors provided that they can give the editor an address through which they can be reached without delay and can guarantee to return the corrected proofs to the editor, by airmail where appropriate, within ten days of receiving them. The master proof will always be sent direct to the editor by the printer; contributors will receive duplicates.

10. Authors of articles and review articles (but not book reviews) receive twentyfive free offprints. Additional copies may be bought if ordered at proof stage. 11. Contributors of accepted articles will be asked to assign their copyright, on certain conditions, to Cambridge University Press, to help protect their material, particularly in the USA. 


\section{TABLE OF CONTENTS}

\section{ARTICLES}

DONALD E. CHAMBERS: Workmen's Compensation in the United States: the Effects of Fifty Years of Local Control and Private Enterprise on the Administration of a Social Welfare Programme

DEPARTMENT OF HEALTH AND SOCIAL SECUR ITY: Social Security Research Activities of the DHSS

PAUL WILDING and VIC GeORGe: Social Values and Social Policy

SHEILA HEWETT, PETER RYAN and JOHN WING: Living without the Mental Hospitals

Kathleen m. Slack: Social Administration Digest

\section{BOOK REVIEWS}

BARBARA wootton: Incomes Policy: An Inquest and a Proposal (Derek Robinson)

RICHARD M. TIT muss: Social Policy: An Introduction (Hugh Heclo)

KATHLeen Jones (ed.): The Year Book of Social Policy in Britain 1973 (Andrew Dunsire)

DENNIS LeES and STElla SHAw (eds.): Impairment, Disability and Handicap (Mavis Maclean)

CENTRAL COUNCIL FOR EDUCATION AND TRAINING IN SOCIAL WORK: Social Work Curriculum Study: Legal Studies in Social Work Education (Harry Street)

MICHAEL ZANDER: Social Workers, Their Clients and the Law (Harry Street)

MARTIN DAVIES: Prisoners of Society: Attitudes and After-Care (Phyllida Parsloe)

R. G. PER R : Information for the Court: A New Look at Social Inquiry Reports (Phyllida Parsloe)

ALLAN OR NSTEIN: Race and Politics in School and Community Organizations (J. S. Fuerst)

IVY PINCHBECK and MARGARET HEWITT: Children in English Society Volume

II: From the Eighteenth Century to the Children Act 1948 (Pat Thane)

AlFred John dimaio, Jr.: Soviet Urban Housing (Michael Harloe)

(C) CAMBRIDGE UNIVERSITY PRESS 1975

Cambridge University Press

Bentley House, 200 Euston Road, London NW1 2DB

32 East 57th Street, New York, N.Y. 10022 